\title{
The attitudes of IVF patients treated in the Czech Republic towards informing children born after gamete donation
}

\author{
Tatana Rumpikova ${ }^{\mathrm{a}, \mathrm{b}}$, Ivana Oborna ${ }^{\mathrm{b}}$, Silvie Belaskova ${ }^{\mathrm{c}}$, Hana Konecna ${ }^{\mathrm{d}}$, David Rumpik ${ }^{\mathrm{a}}$
}

\begin{abstract}
Background. In recent decades gamete donation has received growing attention. Data from the Czech National Registry of Assisted Reproduction show that the number of cycles using donated oocytes has been increasing every year. According to Czech law, gamete donation is anonymous. Since 2011, some members of the Czech parliament have repeatedly made requests to revoke the anonymity but anonymity is one of the preconditions for such donation in this country. The aim of this study was to find out how the gamete recipients feel towards informing their child about the circumstances of their conception and their access to the identity of the donor.

Methods. A total of 195 recipients (122 women undergoing treatment - 43 Czechs, 79 foreigners (Western Europe and the USA) and 73 male partners - 28 Czechs, 45 foreigners) participated in this survey. The data were obtained by anonymous questionnaire.

Results. A significant difference between the attitude of the future Czech and foreign parents regarding disclosing the mode of conception was found $(P=0.003)$. The vast majority of $C z e c h s$ were against disclosure. The foreign recipients were somewhat more divided. Regarding the donor's identity, there was no difference in atttitude between the groups. Recipients rarely consider that the knowledge of the donor's identity will be important for their child. The recipients overall, were convinced that the psychological aspects of parenting are far more important to the child than genetics, and see no reasons for disclosing the donor's identity.

Conclusion. While the the foreign recipients were less adamant about non-disclosure, the overall finding was in accord with the current Czech law on anonymity and not in agreement with the proposed abolition. The recipient's attitudes towards disclosing were also culturally determined. The fact that some countries have revised their rules towards open idendity is not a rationale for such change in the Czech Republic.
\end{abstract}

Key words: gamete donation, anonymity, open identity, parenting, donor's offspring

Received: March 21, 2017; Accepted with revision: November 13, 2017; Available online: December 4, 2017 https://doi.org/10.5507/bp.2017.050

${ }^{a}$ Clinic of Reproductive Medicine and Gynecology Zlin, Czech Republic

${ }^{b}$ Department of Obstetrics and Gynecology, Faculty of Medicine and Dentistry, Palacky University Olomouc, Czech Republic

'International Clinical Research Center, St. Anne's University Hospital Brno, Czech Republic

${ }^{d}$ Faculty of Health and Social Studies, University of South Bohemia, Ceske Budejovice, Czech Republic

Corresponding author:Tatana Rumpikova, e-mail: tatana.rumpikova@ivfzlin.cz

\section{INTRODUCTION}

The number of births originating from donated gametes and embryos is on the rise, where there is no genetic link between the child, the father or the mother, or both ${ }^{1}$. Due to women delaying motherhood, oocyte donation from healthy donors has become one of the most frequently used techniques ${ }^{2}$. Data from the National Registry of Assisted Reproduction ${ }^{3}$ show that the number of cycles using donated oocytes has been increasing every year in the Czech Republic. In accordance with the most recent Czech Act on Specific Health Services (Act No. 373/2011 $\mathrm{Sb}$.), only anonymous donation is allowed. All authorized clinics in which assisted reproduction is performed are responsible for maintaining the anonymity and the prospective parents of the child and the child will obtain only non-identifying information about the donor. Identifying information about the donor's record must be kept for at least 30 years following the use of gametes.

A very important ethical issue is the well-being of children born as a result of this treatment. Should these chil- dren know about the way they were conceived? Do they have the right to know? Do recipient-parents have a duty to tell their donor-conceived child about their genetic origins? In the earliest days of sperm donation treatment, the common practice was to keep information about donor's identities confidential ${ }^{4}$. In the past few decades, knowing his/her genetic origin has been considered a child's right. Contributing factors to this are the increasing importance of genetics in medical decision-making, a change in social openness and an increased societal acceptance in the matter of reproductive donation. A growing number of countries have legislated for open-identity donation, in which donor-conceived offspring are given access to the donor's identity once the child has reached maturity ${ }^{5,6}$. The first country to abolish donor anonymity and introduce a new law in favour of children's right to know the truth about his or her genetic makeup was Sweden in 1985. Other countries with a non-anonymous donation system are for example the UK, Germany, Norway, the Netherlands, Finland, Switzerland, New Zealand and Australia ${ }^{7}$.

In countries where anonymity has been abolished, 
Table 1. The background characteristics of the recipients of donated gametes; P-values represents hypothesis testing based on Pearson Chi-square test.

\begin{tabular}{|c|c|c|c|c|c|c|c|c|c|c|c|c|}
\hline \multirow{2}{*}{\multicolumn{2}{|c|}{ Recipients characteristics }} & \multicolumn{2}{|c|}{$\mathrm{MC}$} & \multicolumn{2}{|r|}{$\mathrm{FC}$} & \multicolumn{2}{|c|}{ MF } & \multicolumn{2}{|c|}{$\mathrm{FF}$} & \multicolumn{2}{|c|}{ Totals together } & \multirow{2}{*}{$P$} \\
\hline & & $\mathrm{n}$ & $\%$ & $\mathrm{n}$ & $\%$ & $\mathrm{n}$ & $\%$ & $\mathrm{n}$ & $\%$ & $\mathrm{n}$ & $\%$ & \\
\hline \multirow[t]{9}{*}{ Age(years) } & $23-27$ & 1 & 3.57 & 2 & 4.65 & 1 & 2.22 & 1 & 1.32 & 5 & 2.60 & \multirow{9}{*}{$<0.001$} \\
\hline & $28-32$ & 9 & 32.14 & 17 & 39.53 & 6 & 13.33 & 6 & 7.89 & 38 & 19.79 & \\
\hline & $33-37$ & 7 & 25.00 & 6 & 13.95 & 6 & 13.33 & 15 & 19.74 & 34 & 17.71 & \\
\hline & $38-41$ & 3 & 10.71 & 9 & 20.93 & 15 & 33.33 & 24 & 31.58 & 51 & 26.56 & \\
\hline & $42-45$ & 2 & 7.14 & 5 & 11.63 & 6 & 13.33 & 12 & 15.79 & 25 & 13.02 & \\
\hline & $46-49$ & 3 & 10.71 & 4 & 9.30 & 5 & 11.11 & 18 & 23.68 & 30 & 15.63 & \\
\hline & $50-53$ & 2 & 7.14 & 0 & 0.00 & 0 & 0.00 & 0 & 0.00 & 2 & 1.04 & \\
\hline & 54 and more & 1 & 3.57 & 0 & 0.00 & 6 & 13.33 & 0 & 0.00 & 7 & 3.65 & \\
\hline & Answers available & 28 & 100.00 & 43 & 100.00 & 45 & 100.00 & 76 & 100.00 & 192 & 100.00 & \\
\hline \multirow[t]{4}{*}{ Education } & Technical/Trade graduate & 8 & 28.57 & 6 & 13.95 & 2 & 4.44 & 2 & 2.53 & 18 & 9.23 & \multirow{4}{*}{$<0.001$} \\
\hline & High school graduate & 11 & 39.29 & 24 & 55.81 & 9 & 20.00 & 7 & 8.86 & 51 & 26.15 & \\
\hline & College graduate & 9 & 32.14 & 13 & 30.23 & 34 & 75.56 & 70 & 88.61 & 126 & 64.62 & \\
\hline & Answers available & 28 & 100.00 & 43 & 100.00 & 45 & 100.00 & 79 & 100.00 & 195 & 100.00 & \\
\hline \multirow{3}{*}{$\begin{array}{l}\text { Marital } \\
\text { status }\end{array}$} & First & 21 & 75.00 & 34 & 79.07 & 34 & 75.56 & 49 & 64.47 & 138 & 71.88 & \multirow[t]{3}{*}{0.308} \\
\hline & Second & 7 & 25.00 & 9 & 20.93 & 11 & 24.44 & 27 & 35.53 & 54 & 28.13 & \\
\hline & Answers available & 28 & 100.00 & 43 & 100.00 & 45 & 100.00 & 76 & 100.00 & 192 & 100.00 & \\
\hline \multirow{3}{*}{$\begin{array}{l}\text { Parental } \\
\text { status }\end{array}$} & Have child & 11 & 39.29 & 10 & 23.26 & 8 & 17.78 & 20 & 25.97 & 49 & 25.39 & \multirow[t]{3}{*}{0.226} \\
\hline & Childless & 17 & 60.71 & 33 & 76.74 & 37 & 82.22 & 57 & 74.03 & 144 & 74.61 & \\
\hline & Answers available & 28 & 100.00 & 43 & 100.00 & 45 & 100.00 & 77 & 100.00 & 193 & 100.00 & \\
\hline
\end{tabular}

parents are recommended to be open with their children and inform them about their conception using donated gametes $^{8-10}$. Although disclosing the details of the child's conception is becoming more common, a significant number of parents delay the intention of disclosing or decide not to tell their child at all ${ }^{11-13}$. In cases of anonymous donation, one of the reasons mentioned is the fact that the child cannot obtain any identifying information about the donor anyway ${ }^{14,15}$. One found that a half of the parents who chose anonymous donation, had done so to maintain confidentiality ${ }^{16}$. Many couples who were determined to maintain secrecy, expressed fears of social stigma surrounding this method of conception ${ }^{17}$. Others wished to protect the offspring from potential negative consequences for the family ${ }^{7,18}$. Not knowing the donor to help the children establish clear boundaries between everyone involved and avoid interference of the donor in the future parent-child relationship ${ }^{16,19}$. A large group of parents believe that the psychological and social aspects of parenting are far more important to a child than genetics, as proven by some well-known psychologists about psychological deprivation Bowlby ${ }^{20,21}$, Matejcek ${ }^{22,23}$. As observed in some studies ${ }^{17,19,24}$ recipient-parents believed their decision - disclose or not disclose - to be in the best interest of the child.

In the Czech Republic, the ethical issues associated with the gamete donation have never been closely investigated. The aim of this study was to provide insight into who the IVF patients in the Czech donation program are and what are their opinions on psychological issues regarding gamete donation.

\section{MATERIALS AND METHODS}

\section{Respondents}

This study on recipients treated by donate gametes was performed in two Czech IVF centres between the years 2012 - 2015 and was based on an anonymous questionnaire. We decided to use a mixed research strategy; a combination of qualitative and quantitative questions to capture as much opinion from each side as possible. In addition to the basic socio-demographic aspects of the recipients, we focused on the ethical problems, especially on the issues connected with informing the child about their conception.

\section{Participants}

A total of 195 recipients participated in this study. Out of this sample, 122 were women undergoing treatment - 43 from the Czech Republic, 79 from foreign countries. The remaining 73 were partners of the patients - 28 Czechs, 45 foreigners. Although the questionnaire was given to both partners, more women filled it out than men.

\section{Data gathering}

An anonymous questionnaire with open and closed questions was designed. For the closed questions a simple scale which consisted of three choices: agree, don't know and disagree was used. The closed questions were focused on both the socio-demographic (non-identifying) characteristics of respondents (age, education, marital and parental status), as well as some ethical topics closely connected to gamete donation. The recipients were asked about their attitudes toward secrecy or disclosure of the method of conception towards the child, what type of 
Table 2. The couple's main attitudes towards openness or secrecy concerning the mode of conception to the child grouped by gender and nationality. Male Czech (MC), female Czech (FC), male foreigner (MF) and female foreigner (FF) are considered; relationship was evaluated using Chi-square test.

\begin{tabular}{|c|c|c|c|c|c|c|c|c|c|c|c|c|}
\hline \multirow[t]{2}{*}{ Question } & \multirow[t]{2}{*}{ Answer } & \multicolumn{2}{|r|}{$\mathrm{MC}$} & \multicolumn{2}{|r|}{$\mathrm{FC}$} & \multicolumn{2}{|r|}{ MF } & \multicolumn{2}{|r|}{ FF } & \multicolumn{2}{|c|}{$\begin{array}{l}\text { Totals } \\
\text { together }\end{array}$} & \multirow[t]{2}{*}{$P$} \\
\hline & & $\mathrm{n}$ & $\%$ & $\mathrm{n}$ & $\%$ & $\mathrm{n}$ & $\%$ & $\mathrm{n}$ & $\%$ & $\mathrm{n}$ & $\%$ & \\
\hline \multirow{4}{*}{$\begin{array}{l}\text { 1. Should offspring be } \\
\text { informed about the } \\
\text { circumstances of their } \\
\text { conception? }\end{array}$} & Yes & 5 & 17.86 & 4 & 10.00 & 16 & 35.56 & 29 & 40.28 & 54 & 29.19 & \multirow{4}{*}{0.003} \\
\hline & No & 23 & 82.14 & 30 & 75.00 & 27 & 60.00 & 38 & 52.78 & 118 & 63.78 & \\
\hline & Don't know & 0 & 0.00 & 6 & 15.00 & 2 & 4.44 & $J$ & 6.94 & 13 & 7.03 & \\
\hline & Ans & 28 & 100.00 & 40 & 0 & 45 & & 72 & 0 & 185 & 100.00 & \\
\hline \multirow{4}{*}{$\begin{array}{l}\text { 2. Do you intend to tell } \\
\text { to your child that he/ } \\
\text { she was conceived from } \\
\text { donated gametes? }\end{array}$} & Yes & 4 & 14.29 & 4 & 10.00 & 15 & 34.09 & 30 & 44.12 & 53 & 29.44 & \multirow{4}{*}{0.001} \\
\hline & No & 23 & 82.14 & 30 & 75.00 & 27 & 61.36 & 35 & 51.47 & 115 & 63.89 & \\
\hline & Don't know & 1 & 3.57 & 6 & 15.00 & 2 & 4.55 & 3 & 4.41 & 12 & 6.67 & \\
\hline & Answers avail & 28 & 100.00 & 40 & 100.00 & 44 & 100.00 & 68 & 100.00 & 180 & 100.00 & \\
\hline \multirow{4}{*}{$\begin{array}{l}\text { 3. Is it important for } \\
\text { your child to know who } \\
\text { the donor is? }\end{array}$} & Yes & 2 & 7.14 & 1 & 2.44 & 2 & 4.44 & 7 & 9.09 & 12 & 6.28 & \multirow[t]{4}{*}{0.370} \\
\hline & No & 26 & 92.86 & 38 & 92.68 & 42 & 93.33 & 70 & 90.91 & 176 & 92.15 & \\
\hline & Don't know & 0 & 0.00 & 2 & 4.88 & 1 & 2.22 & 0 & 0.00 & 3 & 1.57 & \\
\hline & Answers available & 28 & 100.00 & 41 & 100.00 & 45 & 100.00 & 77 & 100.00 & 191 & 100.00 & \\
\hline
\end{tabular}

information should the child have access to - identifying or non-identifying - and whether they intend to inform their child about his/her origin. The open questions then offered space to justify the extent of the respondent's answer to the closed question. When filling out the questionnaire the respondents were guaranteed anonymity. The recipients and their partners filled out the questionnaires separately during their treatment at the clinic. This study was approved by the Ethics Committee of the Institution.

\section{Data analysis}

The basic socio-demographic data were collected - age, education, marital and parental status. The age, due to the anonymity was sorted into the following categories: a: 18 22 years, b: 23-27 years, c: 28-32 years, d: 33-37 years, e: 38-41 years, f: $42-45$ years, g: 46-49 years, h: 50-53 years, i: 54 years and more for recipients. In accordance with the law of the Czech Republic only women up to 49 years of age can undergo IVF treatment, therefore the age scales $h$ : 50-53 years and i: 54 years and more were created for men only. The education of the respondents was divided into three groups - technical/trade graduate, high school graduate or university degree, the marital status was formed of two groups - first and second marriage/relationship and the parental status was formed of two groups as well - have children and childless. The outcomes for each of the main attitudes were stratified by gender crossed with nationality (female - recipient of donate gamete (Czech$\mathrm{FC}$, foreigner-FF) or male - recipient of donated gamete (Czech-MC, foreigner-MF)). For assessing the attitudes and perspectives of the recipients a three point scale was used (agree, disagree and neutral or "don't know").

The associations between the demographic factors were analysed using the Chi square test. All the statistical analyses were performed using the Dell Statistica programme, version 13 (Dell Inc. (2015)). A $P$-value < 0.05 was considered significant.

\section{RESULTS}

\section{The socio-demographic characteristic of the recipients}

The data are presented in Table 1.

The most prevalent characteristics among the Czech recipients were secondary education (49\%), first marriage (78\%) and childlessness (70\%). The foreign recipients characteristics were higher education $(84 \%)$, first marriage $(69 \%)$ and childlessness $(77 \%)$. The foreign recipients undergoing treatment with donated gametes were older than the Czech recipients $(P<0.001)$.

\section{The recipients' basic attitudes towards disclosing}

The opinions of the recipients on informing the child about their genetic origin, their intention to disclose and their opinions on the importance of donor's identity for the child are summarized in Table 2.

Question 1. Of all of the recipients responses ( $n=185)$, almost two thirds - 118 (64\%), refuse to inform the child about the circumstances of his/her conception, 54 recipients $(29 \%)$ were for disclosing and 13 recipients (7\%) were hesitant. There was a significant difference between the Czech and the foreign couples regarding disclosing the mode of conception to their child, $\chi 2(6, n=185)=$ $19.69, P=0.003$. The vast majority of the Czechs $(82 \%$ of men and $75 \%$ of women) thought that the child should not be informed about the circumstances of their conception, whereas for the foreigners this attitude was less pronounced ( $60 \%$ of men and $53 \%$ of women).

The opportunity to expand on their answer was taken by some of the recipients, especially by foreigners. Each respondent had the opportunity to express one or several motives. All the reasons were included in our analysis and each was rated separately. The qualitative data gave us a more detailed view of the reasons behind these recipients' decisions. In parentheses is cited how many Czechs (MC, FC) / foreigners (MF, FF) responded. 
Out of the parents who chose to inform their child, the most cited reason by the Czechs was "the genetic uncertainty" (medical reasons). The child should know that he does not share genes with his parents due to possible future genetically conditioned diseases ( $2 \mathrm{MC}, 3 \mathrm{FC} /$ $1 \mathrm{MF}, 1 \mathrm{FF})$. Amongst the foreigners, the most cited reason was "the honesty in the parent-child relationship" (7 MF, $15 \mathrm{FF}$ ) and „to avoid a potentially detrimental effect due to secrecy within the family" (6 MF, $9 \mathrm{FF})$, the second most cited reason was "the child has a right to know" (1MC/ $7 \mathrm{MF}, 7 \mathrm{FF}$ ) and thirdly, "the correct formation of the child's identity" (3 MF, $4 \mathrm{FF}$ ). Another described reason was "to avoid the risk of an accidental disclosure" (1 FC/ 5 FF, 5 MF). Some of them mentioned concerns relating to organ donation, blood testing or genetic profiling which might cause the information to be revealed in the future. Other reasons include "recommendations by the authority" ( $1 \mathrm{FF}$ ) and "to avoid the risk of consanguinity" (1 MC). Some felt that knowing about the conception would show the child "how wanted they were" (1 MF, 2 FF).

The most cited reason for not to inform was "the uselessness of such information" that is not at all important for child's life ( $1 \mathrm{MC}, 3 \mathrm{FC} / 2 \mathrm{MF}, 3 \mathrm{FF}$ ). According to some recipients it could be harmful to the child to disclose the circumstances of conception because "such information could confuse the child and could complicate the formation of his/her identity" their child would not feel 'normal' if they were told and they wanted them to have a normal childhood (1FC/ $4 \mathrm{MF}, 5 \mathrm{FF})$. Some recipients admitted concerns about "the negative effect of disclosure on the relationship between the child and their parents", in particular the non-genetic parent. They were afraid of weakening the non-genetic parent-child relationship (1 MC / $4 \mathrm{MF}, 3 \mathrm{FF}$ ). Other recipients who are against telling the child also felt "the fear of social stigmatization", because gamete donation in their country is not so socially acceptable (2MC, $2 \mathrm{FC} / 1 \mathrm{MF}, 2 \mathrm{FF})$. Some emphasized "their own substantial contribution to the conception of the child" ( $2 \mathrm{MF}, 2 \mathrm{FF}$ ). One of the reasons against informing the child was the "religion" of the recipients $(1 \mathrm{FF})$. Unfortunately, only a minimal number of respondents substantiated their answers. The foreigners expressed their attitudes more often than the Czechs.

Question 2. Parents' intentions to tell, mostly balanced with their general view of informing the offspring about their genetic origin. The Czechs $(68 \%)$ were clearly in favour of not telling the truth to the child in the future whereas the foreign respondents were more open to disclosing the mode of conception, and $40 \%$ of them planned to inform their offspring in the future. There were significant differences between the $\mathrm{Czech}$ and foreigner recipients' intentions to tell the child, $\chi 2(6, n=180)=21.92$, $P=0.001$.

The respondents generally considered the time when they will explain the situation to their child. Most foreigners reported that they would begin "to explain to a child from infancy" (10 MF, $17 \mathrm{FF}$ ). The Czechs wanted to begin "to explain around puberty" (2 MC, 3FC). Some recipients wrote that they would "explain when the child can understand" (5 MF, $10 \mathrm{FF}$ ) and others did not know when and how to explain to a child ( $3 \mathrm{MF}, 5 \mathrm{FF}$ ).

Question 3. The recipients rarely considered that the knowledge of the identity of the donor is important to a child. The vast majority - 176 (92\%) believe that it is not necessary for the child to know the identity of the donor. Only 12 recipients (6\%) called for obtaining identifying information and 3 recipients $(2 \%)$ were still unsure. There was no difference between the Czechs and the foreigners, $\chi 2(6, \mathrm{n}=191)=6.50, P=0.370$.

\section{DISCUSSION}

The practice of gamete donation has received growing attention due to an increasing number of individuals and couples who have resorted to gamete donation ${ }^{1}$. Patients considering the use of donated gametes in fertility treatment have to face several psychological, social and ethical issues. Perhaps the most important of these is whether or not to inform the child of their genetic origin and whether disclosure really is in the child's best interests. The findings from many studies show that one of the main reasons parents give when explaining why they chose to disclose is that they want to be honest with their child and that they feel that the child has the right to know about their origin $^{13,14,18,25}$. Many people consider the importance of knowing their own genetic origin in relation to the future health of the person concerned. Family history ignorance or accidental consanguineous marriage are thus usually overestimated $^{26,27}$.

According to several authors, providing identifying information about the donor is important in terms of developing the child's identity ${ }^{28-30}$. But is genetics really the main creator of personal identity? And is missing identifying information about the donor vital for personal identity development? We found no study, in this context, describing what the meaning of "identity" is. There are many theories concerning identity which are often contradictory ${ }^{31,32}$. A genetic-essentialist understanding of oneself and identity is misleading. It overstates an individual's genetic makeup and downplays other factors that are critical in the development of identity, especially the role of the family, society and the environment ${ }^{33}$. Another complicated term is "parent".

In the Article 7 of the Convention on the Rights of the Child is mentioned: The child shall be registered immediately after birth and shall have the right from birth to a name, the right to acquire a nationality and as far as possible, the right to know and be cared for by his or her parents. Parenthood can be defined genetically (origin of gametes), biologically (pregnancy and birth) or psychosocially. The legal framework of the parenthood is related to each state's legislation. Some countries consider a new layout of the birth certificates where all possible parents may be mentioned. Extensive research in the field of child developmental psychology, above all "attachment theory" of Bowlby ${ }^{20,21}$ and the "psychical deprivation theory" of 
Matejcek $^{22,23}$ clearly answer that psychosocial solid ties are crucial for positive child development.

There is no supporting evidence to the claim that a child needs to know the identity of the donor to create his/her own identity. Knowing one's donor is not in itself a necessary condition for healthy mental development and general well-being of the child ${ }^{34}$. This is consistent with studies showing that children who do not know about their donor conception are doing as well as non-donorconceived children in terms of general emotional, social and behavioural development ${ }^{17,35,36}$. Likewise, other studies found no differences in the children's psychological well-being and the parent-child relationships between the disclosing and the non-disclosing families ${ }^{14,37,38}$.

Our survey disclosed the attitudes of future parents on various aspects of "disclosure". Of all the recipients' responses $(n=185)$, almost two thirds $(64 \%)$ tended toward refusal to inform the child about the circumstances of their conception, less than one third (29\%) were for disclosing and $7 \%$ were hesitant. There was a significant difference between the attitude of Czechs and foreigners, $P=0.003$. The vast majority of the Czechs ( $82 \%$ of men and $75 \%$ of women) thought that the child should not be informed about their genetic origin, whereas within the foreigners this difference was not obvious ( $60 \%$ of men and $53 \%$ of women). But there was no differences between the Czechs and the foreigners in disclosing of the donor's identity. Recipients rarely considered that the knowledge of the identity of the donor is important for a child. Only $6 \%$ of them called for obtaining identifying information.

Human sciences like sociology and psychology take reality as a socially conditioned phenomenon ${ }^{39,40}$. However, there is not just one social reality as Ian Hacking reminds us $^{39}$. We are convinced that the current "disclosure trend" is culturally and socially determined and the decision about disclosure of the mode of conception is entirely up to the parents. The fact that some countries have revised their rules towards open idendity is not the reason for such change in the Czech Republic. Reproductive tourism is growing, due to different conditions within countries, both financial and legal.

Concerning infertility treatment conditions, foreign patients are well informed about Czech legislation. It is their own decision, thir own responsibility and their free choice to come for infertility treatment and gamete donation to the Czech Republic or to any other country offering anonymous gamete donation.

\section{CONCLUSION}

This survey showed that almost two thirds of respondents - 118 (64\%), refuse to inform the planned child about the circumstances of his/her conception, 54 recipients (29\%) were for disclosing and 13 recipients (7\%) were hesitant. There was a significant difference between the Czech and the foreign couples regarding disclosing the mode of conception to their child, $\chi 2(6, n=185)=$ $19.69, P=0.003$. The vast majority of the Czechs $(82 \%$ men and $75 \%$ women) thought that the child should not be informed about the circumstances of their conception, whereas for the foreigners this attitude was less pronounced ( $60 \%$ of men and $53 \%$ of women). The recipients in this survey were predominantly convinced that the psychological and social aspects of parenting are far more important to the child than genetics and they can see no reasons for disclosing.

Acknowledgement: This research has been supported by GACR 17-07753S. Supported by the project no. LQ1605 (MEYS CR, NPU II).

Author contributions: TR: main author, planned and designed the study, colected the data, searched literature, drafted the manuscript, IO: revised and approved the final manuscript, HK: psychological counselling, designed the questionnaire, qualitative analysis, SB: statistical analysis, DR: contributed to the acquisition of the data, assisted in the analysis.

Conflict of interest statement: The authors state that there are no conflict of interest regarding the publication of this article.

\section{REFERENCES}

1. Appleby J, Blake L, Freeman T. Is disclosure in the best interests of children conceived by donation? In: Richards M, Pennings G, Appleby JB, (eds). Reproductive Donation: Practice, Policy and Bioethics. Cambridge; 2012, p.231-249. ISBN 9780521189934.

2. Pennings G, de Wert G, Shenfield F, Cohen J, Tarlatzis B, Devroey P. ESHRE Task Force on Ethics and Law 15: Cross-border reproductive care. Hum Reprod 2008;23:2182-4.

3. UZIS/NRAR. Asistovaná reprodukce v České republice 2014. Praha; 2014, p.25-27. ISBN 9788074721489.

4. Daniels KR, Taylor K. Secrecy and openness in donor insemination. Polit Life Sci 1993;12:155-70.

5. Blyth E, Frith L. Donor-conceived people's access to genetic and biographical history: an analysis of provisions in different jurisdictions permitting disclosure of donor identity. Int J Law Policy Family 2009;23(2):174-91.

6. Freeman T, Zadeh S, Smith, V, Golombok S. Disclosure of sperm donation: a comparison between solo mother and two-parent families with identifiable donors. Reprod BioMed Online 2016;33(5):592-600.

7. Daniels KR, Grace VM, Gillett WR. Factors associated with parents' decisions to tell their adult offspring about the offspring's donor conception. Hum Reprod 2011;26(10):2783-90.

8. Blyth E. How it feels to be a child of donor insemination. BMJ, 2002;234:797.

9. Daniels KR, Thorn P. Sharing information with donor insemination offspring: A child-conception versus a family building approach. Hum Reprod 2001;16(9):1792-6.

10. Blake L, Jadva V, Golombok, S. Parent psychological adjustment, donor conception and disclosure: a follow-up over 10 years. Hum Reprod 2014;29(11):2487-96.

11. Readings J, Blake L, Casey P, Jadva V, Golombok S. Secrecy, disclosure and everything in- between: decisions of parents of children conceived by donor insemination, egg donation and surrogacy. Reprod Biomed Online 2011;22(5):485-95.

12. Sälevaara M, Suikkari AM, Söderström-Anttila V. Attitudes and disclosure decisions of Finnish parents with children conceived using donor sperm. Human Reprod 2013;28(10):2746-54.

13. Applegarth LD, Kaufman NL, Josephs-Sohan M, Christos PJ, Rosenwaks Z. Parental disclosure to offspring created with oocyte donation: intentions versus reality. Hum Reprod 2016;31 (8):1809-15.

14. Lyccet E, Daniels K, Curson R, Golombok S. School-aged children of donor insemination: a study of parents'disclosure patterns. Hum Reprod 2005;20(3):810-9. 
15. Söderström-Anttila V, Sälevaara M, Suikkari, AM. Increasing openness in oocyte donation families regarding disclosure over 15 years. Human Reprod 2010;25(10):2535-42.

16. Laruelle C, Place I, Demeestere I, Englert Y. Anonymity and secrecy options of recipient couples and donors, and ethic origin influence in three types of oocyte donation. Hum Reprod 2011;26(2):382-90.

17. Murray C, MacCallum F, Golombok S. Egg donation parents and their children: Follow-up at age 12 years. Fertil Steril 2006;85(3):610-8.

18. Indekeu A, Dierickx K, Schotsmans P, Daniles KR, Rober P, D'Hoodghe $R$. Factors contributing to parental decision-making in disclosing donor conception: a systematic review. Hum Reprod Update 2013;19(6):714-33.

19. Greenfeld DA, Klock S. Disclosure decisions among known and anonymous oocyte donation recipients. Fertil Steril 2004;81(6):1565-71.

20. Bowlby J. Attachment and loss, Vol. 1: Attachment. New York: Basic Books; 1969.

21. Bowlby J. Attachment and loss, Vol. 2: Separation. New York: Basic Books; 1973.

22. Matějček Z. O rodině vlastní, nevlastní a náhradní. Praha: Portál;1994. ISBN 8085282836. (In Czech)

23. Matějček Z, Bubleová V, Kovařík J. Pozdní následky psychické deprivace. Praha: PCP; 1997. ISBN 8085121891. (In Czech)

24. Isaksson S, Skoog-Svanberg A, Sydsjo G, Linell L, Lampic, C. It takes two to tango: information sharing with offspring among heterosexual parents following identifiable sperm donation. Hum Reprod 2016;31(1):125-32.

25. Lalos A, Gottlieb C, Lalos O. Legislated right for donor-insemination children to know their genetic origin: A study of parental thinking. Hum Reprod 2007;22(6):1759-68.

26. Cahn, N. Accidental Incest: Drawing the Line-or the Curtain-for Reproductive Technology. Harv J L \& Gender 2009;32:59-107.

27. Sawyer, N. Sperm donor limits that control for the 'relative' risk associated with the use of open-identity donors. Hum Reprod 2010;25(5):1084-96.

28. Ravitski V. Knowing Where You Come From: The Rights of DonorConceived Individuals and the Meaning of Genetic Relatedness. Minnesota J Law Science Technology 2010;11:655-84.
29. McWhinnie A. Gamete donation and anonymity: should offspring from donated gametes continue to be denied knowledge of their origins and antecedents? Hum Reprod 2001;16(5):807-17.

30. Velleman JD. Persons on prospect. Philosophy \& Public Affairs 2008;36:21-288.

31. Konečná $\mathrm{H}$, Klůfa J, Doskočil $\mathrm{O}$, Bubleová V. Anonymní dárcovstvî gamet a anonymní porody: společné eticko-psychosociální a právní aspekty. (Anonymous donation of gametes and anonymous births: common ethical, psychosocial and legal aspects). Praktický lékař 2012;92(10):498-502. (In Czech)

32. Konečná H. O "negenetickém" rodičovství trochu jinak. Vydalo Středisko náhradní rodinné péče, Praha 2012. ISBN 978-80-8745511-1. (In Czech)

33. Sabatello M. Regulating Gamete Donation in the U.S.: Ethical, Lega and Social Implications. Laws 2015;4(3):352-76.

34. Ravelingien A, Provoost, V, Pennings, G. Donor-conceived children looking for their sperm donor: what do they want to know? FVV in OBGYN 2013;5(4):257-64.

35. Golombok S, Brewaeys A, Cook R, Giavazzi MT, Guerra D, Mantovan A, van Hall E, Crosiqnati PG, Dexeus S. The European Study of Assisted Reproduction Families. Hum Reprod 1996;11(10):2324-31.

36. Golombok S, Brewaeys A, Giavazzi MT, Guerra D, MacCallum F, Rust J. The European Study of Assisted Reproduction Families: The transition to adolescence. Hum Reprod 2002;17(3):830-40.

37. Golombok S, Readings J, Blake L, Casey P, Mellish L, Marks A, Jadva V. Children conceived by gamete donation. The impact of opennes about donor conception on psychological adjustment and parentchild relationships at age 7. J Fam Psychol 2011;25(2):230-9.

38. Golombok S, Blake L, Casey P, Roman G, Jadva V. Children Born Through Reproductive Donation: A Longitudinal Study of Psychological Adjustment. J Child Psychol Psychiatry 2013;54(6):653660.

39. Hacking I. The Social Construction of What? Harvard University Press; November 2000. ISBN 9780674004122

40. Berger, P, Luckmann, T. Sociální konstrukce reality: Pojednání o sociologii vědění. Praha: Centrum pro studium demokracie a kultury; 1999. ISBN 8085959461. 